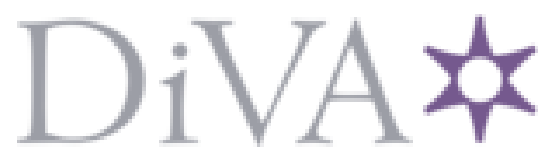

http://www.diva-portal.org

This is the published version of a paper published in Applied Vegetation Science.

Citation for the original published paper (version of record):

Dynesius, M., Åström, M., Nilsson, C. (2008)

Microclimatic buffering by logging residues and forest edges reduces clear-cutting impacts on forest bryophytes.

Applied Vegetation Science, 11 (3): 345-354

http://dx.doi.org/10.3170/2008-7-18457

Access to the published version may require subscription.

N.B. When citing this work, cite the original published paper.

Permanent link to this version:

http://urn.kb.se/resolve?urn=urn:nbn:se:umu:diva-1 1441 


\title{
Microclimatic buffering by logging residues and forest edges reduces clear-cutting impacts on forest bryophytes
}

\author{
Dynesius, Mats*; Åström, Marcus \& Nilsson, Christer \\ Landscape Ecology Group, Department of Ecology and Environmental Science, Umeå University, SE-901 87 Umeå, Sweden; \\ "Corresponding author; E-mail mats.dynesius@emg.umu.se
}

\begin{abstract}
Question: The practice of extracting logging residues after clear-cutting for bioenergy purposes is spreading. Logging residues constitute a shelter in clear-cut areas and therefore concerns have been expressed that their removal could make the ground and its vegetation more exposed to extreme microclimatic conditions. We asked whether logging residues and forest edges can protect ground-dwelling forest bryophytes from fatal microclimate events following clear-cutting.

Location: Boreal forests of central Sweden.

Methods: Using transplants of eight forest floor bryophyte species we experimentally analysed the sheltering effect (less solar radiation and less wind) of logging residues and forest edges in seven clear-cut areas. Transplants were placed in two contrasting positions in each area; near a north-facing forest edge and in the centre of the clear-cut area. In each position, half of the transplants were covered by a layer of spruce branches and the other half was left uncovered. We estimated proportion of apparently living shoots (apparent vitality) and measured radial growth of transplants during one growing season.

Results: Position in the clear-cut area, but not cover of spruce branches, clearly influenced radial growth. Vitality scores were higher among transplants covered with branches and the lowest apparent vitality was observed in uncovered transplants in the middle of clear-cut areas. The change in area of apparently living shoots during the course of the experiment (growth minus mortality) was unaffected by branch cover close to the edge but positively affected in the centre of the clear-cut area. In general, the effect of branch cover on bryophytes was higher in the centre of clear-cut areas. Here, climatic measurements showed that branch cover buffers during periods of extreme microclimates.

Conclusions: Extraction of logging residues after clear-felling may reduce the survival of some ground-dwelling forest organisms. The additional sheltering provided by branches was unimportant close to forest edges. We suggest smaller clear-cut areas, green-tree retention and other ways to make logged areas shadier and less windy to mitigate the reduced shelter caused by harvest of logging residues.
\end{abstract}

Keywords: Disturbance; Edge effect; Habitat quality; Liverwort; Logging residue; Picea abies; Slash.

Nomenclature: Hallingbäck et al. (2006) for bryophytes and Krok \& Almquist (1994) for vascular plants.

\section{Introduction}

The ground is warmer during daytime and colder at night in a clear-cut area compared to a forest (Keenan \& Kimmins 1993) and clear-cut areas generally experience higher wind velocity close to the ground (Chen et al. 1993). These factors affect physical and physiological processes that, in turn, influence species persistence and colonization. Forest mosses and liverworts (bryophytes) and other organisms that can neither seek shelter nor effectively control water uptake or loss are particularly vulnerable to the microclimatic changes caused by clear-cutting (Hylander et al. 2005). For bryophytes, microclimate is a key factor for growth, mortality and reproduction (Økland 1997; Rydgren \& Økland 2002). Under a closed canopy, air moisture close to the ground may be high, fed by evapotranspiration from the ground and the understorey vegetation. The increased daytime temperature at ground level after canopy removal lowers air moisture, which is further depressed by increased wind speeds. The resulting longer periods in a dehydrated state may reduce bryophyte growth and increase shoot mortality, although lower night temperatures may reduce losses through respiration.

Forest bryophytes may persist in clear-cut areas in sheltered positions where the microclimate is more similar to pre-harvest conditions. For example, northern slope aspect or remnant canopies moderate the microclimate and its negative effects on forest bryophytes (Fenton \& Frego 2005; Hylander et al. 2005; Heithecker \& Halpern 2006; Åström et al. 2007). Shading by shrubs, logs and stumps improve survival and growth of plants typical of shady habitats in otherwise exposed settings (Busby et al. 1978; Minore 1986; Gray \& Spies 1997).

Post-harvest extraction of logging residues (e.g. treetops, branches and twigs) is increasing to meet the rising demand for renewable energy (Proe et al. 1994; Doherty et al. 2002). This practice reduces shelter and heterogeneity following clear-cutting (Gunnarsson et al. 2004; Åström et al. 2005) and adversely affects many forest bryophytes (especially liverworts), whereas occasional 
moss species in acrocarpous ground-living genera such as Dicranum and Polytrichum may increase (Nykvist 1997; Åström et al. 2005). Several studies suggest that logging residues shelter forest plants (Olsson \& Staaf 1995; Bråkenhielm \& Liu 1998; Åström et al. 2005), but this has not been tested in controlled manipulative experiments and the spatial variation of the sheltering effect within a clear-cut area has not been established.

This experiment was designed to test if logging residues buffer microclimate and thereby promote survival and growth of forest floor bryophytes when Picea abies stands are clear-felled and if this effect varies with proximity to north-facing forest edges. North-facing edges provide shade during the mid-day peak of solar radiation but also shelter from wind. We expected that cover by spruce branches would improve growth and vitality of forest bryophytes by buffering radiation and temperature and that this effect would be smaller close to forest edges.

\section{Methods}

\section{Study area}

Our study was conducted in the middle boreal zone (Ahti et al. 1968) in the southernmost part of the province of Angermanland in central Sweden between $62^{\circ} 50^{\prime}$ and $63^{\circ} 05^{\prime} \mathrm{N}$. The growing season is ca. 150 days; mean monthly temperatures for May, June, July, August and September are 7, 13, 15, 14 and $9{ }^{\circ} \mathrm{C}$, respectively. Mean monthly precipitation for these months are 35, 40, 60, 70 and $70 \mathrm{~mm}$, respectively (Raab \& Vedin 1995). Compared to the mean monthly temperatures, June 2003 (the year of the experiment) was $1{ }^{\circ} \mathrm{C}$ colder, July $4{ }^{\circ} \mathrm{C}$ warmer and August and September $1{ }^{\circ} \mathrm{C}$ warmer. The precipitation in June, July, August and September 2003 was $6 \mathrm{~mm}$ above, $43 \mathrm{~mm}$ below, $68 \mathrm{~mm}$ above and 34 mm below means, respectively. Weather data for 2003 are from Lännäs weather station (temperature) and from Lännäs and Kramfors weather stations (precipitation) located $21 \mathrm{~km}$ and $13 \mathrm{~km}$, respectively, from the midpoint of the study area (courtesy of Swedish Meteorological and Hydrological Institute). The coniferous forests in the area have been intensively managed for wood production for the last 150 years. Selective cuttings totally dominated the early management, but clear-cutting has been the main mode of timber harvest for the last 50-60 years (Wastenson \& Nilsson 1995).

\section{Bryophyte species}

We selected six pleurocarpous mosses and two leafy liverworts that are common components in the understorey in mesic-moist Picea abies forests in the study area. We excluded vertically growing species (acrocarps) for methodological reasons. The species were chosen to represent a range of tolerance to open habitats. The mosses Hylocomium splendens, Pleurozium schreberi and Rhytidiadelphus triquetrus are assumed to be the least moisture demanding of the eight species and Hylocomiastrum umbratum, Ptilium crista-castrensis and the liverwort Plagiochila asplenioides are considered to be the most shade-tolerant (Ellenberg et al. 1992). The liverwort Barbilophozia lycopodioides and the moss Rhytidiadelphus subpinnatus are considered to be more moisture demanding than the first group of species and less shade-tolerant than the second group (Ellenberg et al. 1992). Another selection criterion was that the species should frequently grow in more or less mono-specific patches to facilitate the collection of transplants.

H. umbratum is encountered in shady and humid habitats and is relatively sensitive to edge effects (Hylander 2005). In the southern and middle parts of Sweden (including the study area) its presence is considered to indicate long forest continuity and constantly high air moisture (Nitare 2000). H. splendens is abundant and often dominates mesic ground. It is highly resilient to herbivory and small-scale disturbance (Økland 1995; Rydgren et al. 2001). P. schreberi is abundant in dry to mesic forests, but may also grow in relatively open habitats. R. subpinnatus occurs mostly in humid Picea forests and is considered indicative of species-rich habitats with high conservation value, particularly in the southern and middle parts of Sweden (Nitare 2000); whereas $R$. triquetrus is primarily encountered in drier microhabitats in herb-rich communities. P. asplenioides is restricted to shady and moist habitats, whereas $B$. lycopodiodes may grow there but also occurs in exposed sites (Damsholt 2002).

Monospecific mats of each species were collected from the forest floor of mature forests within the study area to be used as transplants. Loose substrate attached to bryophytes was removed together with the mats, but the soil was not dug up. All species grew on litter and humus on the ground. When target species occurred near the clear-cut areas we collected transplants immediately before transplantation. In other cases we collected transplants in advance and stored them for a few days in a shady and moist Picea swamp forest until transplantation.

\section{Experimental setup}

We used a database provided by the forest company SCA to select seven recently clear-cut Picea-dominated stands with an adjacent north-facing forest edge that was at least $15 \mathrm{~m}$ high and $30 \mathrm{~m}$ wide. In each clear-cut area we located two sites with similar vegetation and soil 
moisture conditions. One site was positioned close to the north-facing edge (ca. $10 \mathrm{~m}$ from the edge) and the other in the centre of the clear-cut area (ca. 50-300 m from the north-facing edge, depending on the size of the clear-cut area). In each site we established two $0.7 \mathrm{~m} \times$ $2.1 \mathrm{~m}$ experimental plots. We removed vegetation, roots and stones in the plots and mixed, levelled and gently compacted the soil to minimize internal heterogeneity. In each of the four plots we placed three circular transplants of each species at least $0.1 \mathrm{~m}$ from the plot periphery and $0.1 \mathrm{~m}$ apart. We ensured that the transplants were in close contact with the ground by planting them into shallow depressions, which were filled with water immediately before transplantation. The position of each transplant was randomly selected. Transplants varied in size (21-83 $\mathrm{cm}^{2}$ ) depending on species but we kept the 12 transplants of each species similar with respect to size and appearance within each site. Each transplant was equipped with three vertically inserted plastic pins as reference points. In transit, as well as during and directly after planting, the transplants were sprayed with water.

After transplantation we randomly selected and covered one of the two plots in each position with branches that we collected from living spruces and placed on a $0.7 \mathrm{~m} \times 2.1 \mathrm{~m}$ wooden frame elevated $0.1 \mathrm{~m}$ above the plot surface. The frame enabled temporary removal of the branches during collection of bryophyte response data with minimal disturbance (needle loss etc.). The branches were placed in a single layer, with primary branches $15 \mathrm{~cm}$ apart but with over-lapping secondary branches. The branches, twigs and needles covered ca. $95 \%$ of the plot. In each clear-cut area all transplants and branches were put in place within a day. Altogether we planted 672 bryophyte transplants ( 7 clear-cut areas $\times 4$ treatments $\times 8$ species $\times 3$ replicates) between May 29 and June 5, 2003. By the end of the growing season (September 15-20), 105-114 days after transplantation the experiment was terminated because transplants would have been disturbed (compressed) by snow making relevant further measurements impossible. On two occasions we removed colonizing vegetation within the plots. At the end of the experiment no transplants had grown to merge with adjacent transplants.

Simultaneously to our study, an experiment on wood-ash recycling was conducted, using the same transplantation method and the same species in seven nearby spruce stands (M. Dynesius, unpubl. data). The control plots of this experiment were analysed by us in a similar fashion as the clear-cut plots but they are not formally used as forest control plots, because the number of replicates was small. However, the data are presented in the Discussion and in App. 2 to give a general picture of growth conditions for this particular year and in closed forests compared to clear-cut areas.

\section{Habitat properties}

Clear-cutting was carried out 2-8 years before the experiment and the sites were located 151-239 $\mathrm{m}$ above sea level. Soil type was either a sandy-loamy till (six areas) or loamy sediment (one area). Vegetation type (according to Hägglund \& Lundmark 1987) was either herb type (six areas) or broad-leaved grass type (one area). Site productivity ranged between $5.2-5.7 \mathrm{~m}^{3} \mathrm{sk}$ per ha and year, i.e. trunk volume above stump height potentially produced per ha and year, including the bark (data from SCA).

In the field we measured tree height and basal area of north-facing edges using a Suunto Clinometer and a relascope, respectively. Mean tree height ranged 15-23 $\mathrm{m}$ among sites. Mean basal area of Picea, Pinus and broad-leaved trees were 19,3 and $5 \mathrm{~m}^{2} /$ ha, respectively and basal area of all trees ranged between $21-33 \mathrm{~m}^{2} / \mathrm{ha}$. Distances between plots and edges were determined using a measuring-tape or a laser range finder. The plots at the edges were located $10 \mathrm{~m}$ (range 7-13 m) from northfacing edges. Plots in the centre of clear-cut areas were located $113 \mathrm{~m}$ (range 49-280 m) from north-facing and $96 \mathrm{~m}$ (range 39-310 m) from south-facing edges.

Light intensity $\left(\mathrm{W} / \mathrm{m}^{2}\right)$ was measured at the plot surface at six random points and the plot mean was used for analysis. This measurement was done once in each stand 0-22 days (June) after transplantation during clear days and all readings were taken within a $30 \mathrm{~min}$ time span close to noon. Maximum daytime temperature $\left({ }^{\circ} \mathrm{C}\right)$ inside the most central transplant of $\mathrm{H}$. umbratum was automatically recorded between $0900 \mathrm{hrs}$ and 1800 hrs simultaneously in all four plots in a site using precalibrated digital thermometers with $4 \mathrm{~mm} \times 11 \mathrm{~mm}$ steel probes. This was done on clear days once in each stand 8 to 22 days after transplantation. Soil water content (\% of volume) was measured using a TDR (Time Domain Reflectometer) on September 8 at ten systematically selected points in each plot and the mean was used as one observation in the analyses.

\section{Bryophyte growth and vitality}

We developed a rapid and simple field method to obtain non-destructive assessments of bryophyte growth. Directly after transplantation we drew the outline of the periphery of the vertical projection of each transplant and the position of the reference pins on a plastic film placed on a Plexiglas board situated $6 \mathrm{~cm}$ above the plot surface. At the end of the experiment we used the same plastic film and reference pins to draw a new peripheral projection and outlined patches of dead tissue. It was clearly observed from morphology that the expansion was a result of bryophyte growth and did not depend 
on flattening of the transplant. By using peripheral projections and circle-approximation we calculated the initial and final mean radii of each transplant using the formula: radius $=\sqrt{\text { area } / \pi}$. Area which included both dead and living tissue was calculated using the software UTHSCSA Image Tool 3.0 (Wilcox et al. 1995-2002). Radial growth $(\mathrm{mm})$ was expressed as change in radius rather than change in area to avoid variation in growth caused by variations in initial size of the transplants.

We estimated vitality of each transplant in June (2329 days after transplantation) and in September when the experiment was ended. Vitality was rated in seven classes according to the appearance of the transplant. Only brown and yellow tissue was considered dead. This may underestimate mortality somewhat in some species making the measure of change conservative. The classes were : (1) entire transplant dead; (2) occasional leaves alive; (3) occasional shoots alive; (4) $<1 / 2$ transplant alive; (5) $>1 \frac{1}{2}$ transplant alive; (6) occasional shoots dead; (7) the whole transplant alive (adapted from Hylander et al. 2002). At the start of the experiment all transplants were considered fully vital (7). As a measure of the net change in area of living bryophyte (growth minus mortality) of each species we measured the area (using UTHSCSA Image Tool 3.0) of apparently living green bryophyte tissue at the start and at the end of the experiment and calculated the difference. Before assessing vitality and before drawing vertical projections the transplants were hydrated by spraying water to create similar conditions in all transplants and on all three occasions.

\section{Statistical analyses}

Normality and homogeneity of variances were tested using the Kolmogorov-Smirnov's and Levene's test, respectively. Radial growth of each species was analysed using two-way ANOVAs where branch cover (covered vs not covered) and position (edge vs centre) were considered fixed factors. One-way ANOVAs and posthoc Tukey tests were used to locate differences among treatments in radial growth as well as net change in area of apparently living shoots for each species. For Plagiochila asplenioides, we used square root transformed radial growth data in all analyses to meet assumptions of homoscedasticity and normality.

One-way ANOVAs and post-hoc tests were also applied to locate differences among treatments in plot temperature (Tukey test), soil water content (Tukey test) and radiation. Radiation data were log-transformed to meet assumptions of normality but since homoscedasticity could not be achieved we used Dunnet's C post-hoc test. Reductions in radiation input and temperature caused by branch cover (i.e. pair-wise comparisons between covered and uncovered plots) were compared between plots at edges and in centres of clear-cut areas using the non-parametric Mann-Whitney $U$-test due to nonnormality of the distribution of the reductions.

Pearson correlations were used to analyse the relationships between radiation, temperature and pooled growth of all species (mean of all transplants within a plot) and to investigate the relationship between soil water content and the pooled growth in each of the four treatments. In analyses including apparent vitality we used nonparametric methods as the data were categorical on an ordinal scale. We applied the Kruskal-Wallis $H$-test to analyse differences in final vitality of each species among treatments. The Wilcoxon's signed rank test was used to analyse reductions in apparent vitality four and 15 weeks after transplantation. Spearman rank correlation was used to investigate the relationship between radiation, temperature and pooled apparent vitality.

In analyses of individual species we used plot mean values (from three transplants) as input data (apparent vitality, change in area of apparently living shoots and radial growth). Due to animal (mainly moose) disturbance 5\% of the transplants were excluded. In such cases we instead used the means of the remaining undisturbed transplants in the plot. Since disturbance was sporadic and evenly distributed between plots and stands we obtained data for all species and plots, i.e. $N=7$ throughout the study. SPSS for Windows Version 13.0.1 was used for all statistical analyses (Anon. 1989-2004).

\section{Results}

Across all treatments, light intensity at noon and maximum daily temperature were positively correlated (Pearson's $r=0.71, P<0.0001, n=28$ ) and differed among the four types of plots (One-way ANOVA: $P<$ 0.0001 , df $=3$ for both variables). Both branch cover and proximity to forest edge reduced light intensity. Uncovered plots in the centre of the clear-cut area received ca. 20 times more radiation at noon than branch-covered plots at the edge (Fig. 1A). Branch cover reduced light intensity more in central parts of clear-cut areas than close to edges (mean reduction 648 vs. $242 \mathrm{~W} / \mathrm{m}^{2}$; MannWhitney $U$-test: $P=0.002, n=7$; Fig. 1A), but reduced maximum daily temperature in transplants to a similar extent (ca. $10{ }^{\circ} \mathrm{C}$ ) in both positions (Mann-Whitney $U$-test: $P=0.902, n=7$; Fig. 1B). Position close to the edge reduced maximum temperature by $5{ }^{\circ} \mathrm{C}$ regardless of branch-cover (Fig. 1B). There were no differences in soil water content among treatments (One-way ANOVA: $P=0.893, \mathrm{df}=3$; Fig. 1C).

Across all treatments, radial growth decreased with increasing light intensity and maximum temperature (all species pooled; Pearson's $r=-0.40, P=0.035, n=28$; 

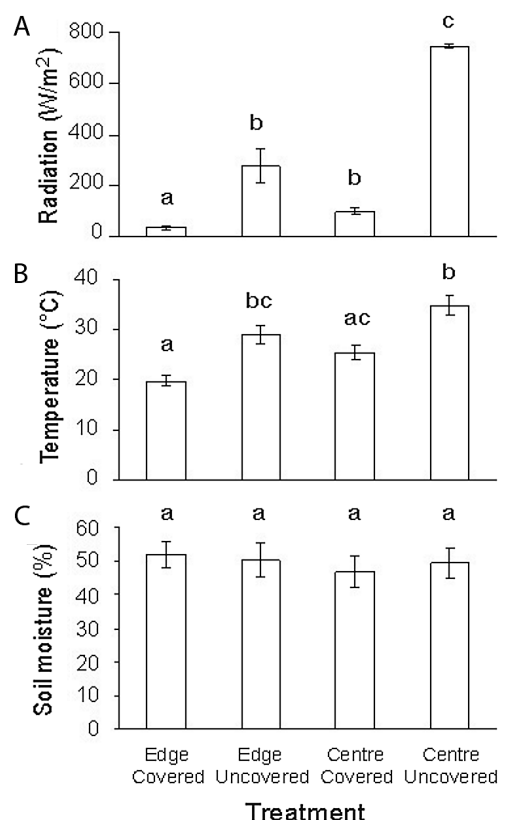

Fig. 1. Light intensity at noon (radiation), maximum daily temperature and soil water content in the four types of plots. Treatment refers to position (close to a forest edge vs in the centre of a clear-cut area) and branch cover (uncovered vs covered with Picea branches). Differences were analysed with one-way ANOVA $(\mathrm{df}=3)$ and the post-hoc tests Dunnett's C (radiation, $n=7$ for all treatments) or Tukey (temperature and moisture, $n=7$ for all treatments). For tests involving radiation $\log$ transformed data were used. ANOVAs for radiation and maximum temperature were significant $(P<0.00001)$, whereas the ANOVA for soil moisture was not $(P=0.893)$. Different letters denote significant $(P<0.005)$ differences between treatments according to post-hoc tests. Data are means $\pm 1 \mathrm{SE}$.

and $r=-0.48, P=0.009, n=28$, respectively). In the uncovered plots at the edge, growth increased with soil water content (all species pooled: Pearson's $r=0.82$, $P=0.024, n=7$ ) but there were no such relationships in the remaining three treatments (Pearson's $r<0.46$, $P>0.136, n=7)$. Plot position in the clear-cut area significantly influenced growth of all species (App. 1) and growth was higher in edge plots (Fig. 2). Only $P$. asplenioides was significantly influenced by branch cover (App. 1) and it tended to grow better in covered plots irrespective of position in the clear-cut area (Fig. 2). Branch cover tended to reduce growth at edges but increase it in central parts of clear-cut areas for all the seven other species (Fig. 2).

For six species apparent vitality was significantly reduced in the uncovered plots in the middle of the clear-cut areas by four weeks after transplantation (Fig. 3d). There were large differences in vitality change among treatments and species. Across all treatments and at the end of the experiment, the vitality of all species pooled was negatively

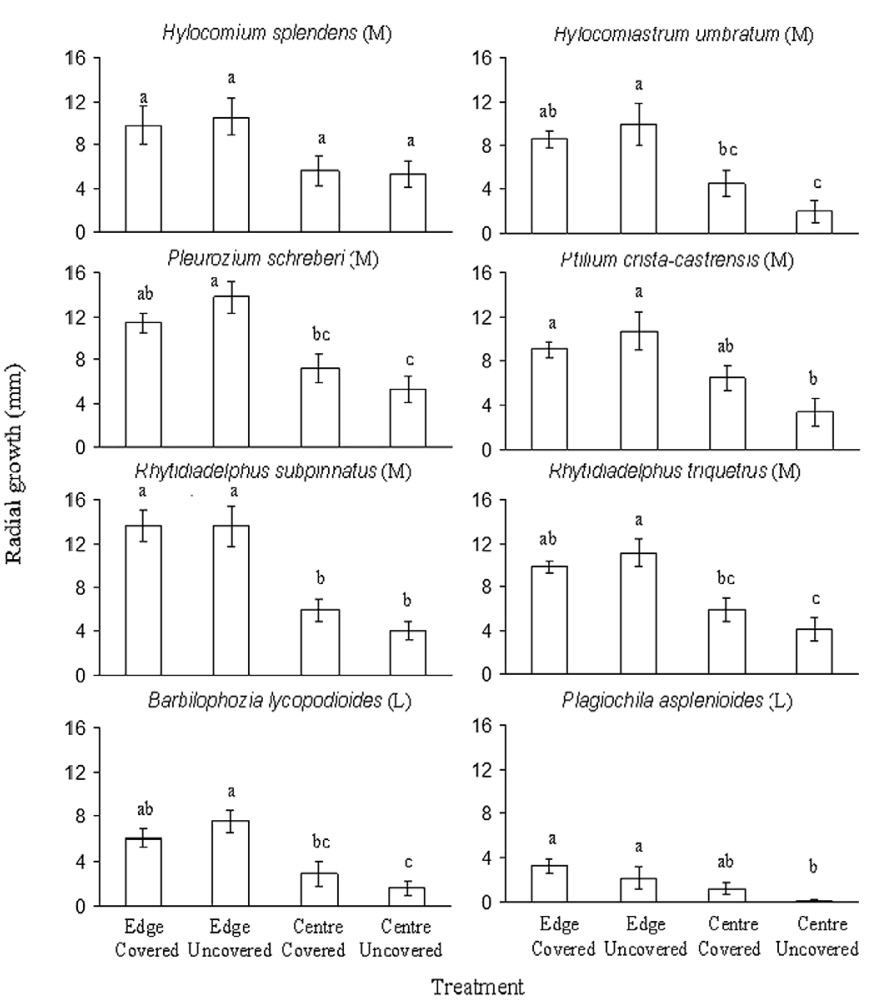

Fig. 2. Radial growth ( $\mathrm{mm}$ ) during the course of the experiment (15 weeks). Treatments refer to position (close to a north-facing forest edge vs in the centre of a clear-cut area) and branch cover (uncovered vs covered with Picea branches). (M) and (L) denote mosses and liverworts. Differences were tested with one-way ANOVA $(\mathrm{df}=3)$ and the Tukey test $(n=7$ for all treatments). For $P$. asplenioides square root transformed data were used in the analyses. All ANOVAs were statistically significant $(P=0.00002-0.044)$. Different letters denote significant $(P<$ $0.05)$ differences between treatments according to Tukey tests. Data are means $\pm 1 \mathrm{SE}$.

correlated with light intensity (Spearman rank correlation: $r=-0.78, P<0.0001, n=28)$ and temperature $(r=-0.74$, $P<0.0001, n=28$ ). All individual species differed in apparent vitality among the four treatments (KruskalWallis test: $P<0.004$, df $=3$; Fig. 3). Species located in plots covered by Picea branches at the edge appeared unaffected (Fig. 3a) and all eight species increased in area of apparently living shoots (Fig. 4). Although transplants in uncovered plots at edges and in plots covered by Picea branches in the central parts of clear-cut areas showed lower apparent vitalities, all species except $P$. asplenioides increased in areas of apparently living shoots (Fig. 4). In contrast, all species located in uncovered plots in central parts of clear-cut areas had deteriorated (Fig. 3). Here, the area of apparently living shoots was reduced for all species except $P$. schreberi and the response typically differed significantly from the other treatments, particularly in relation to edge plots (Fig. 4). The change in area 


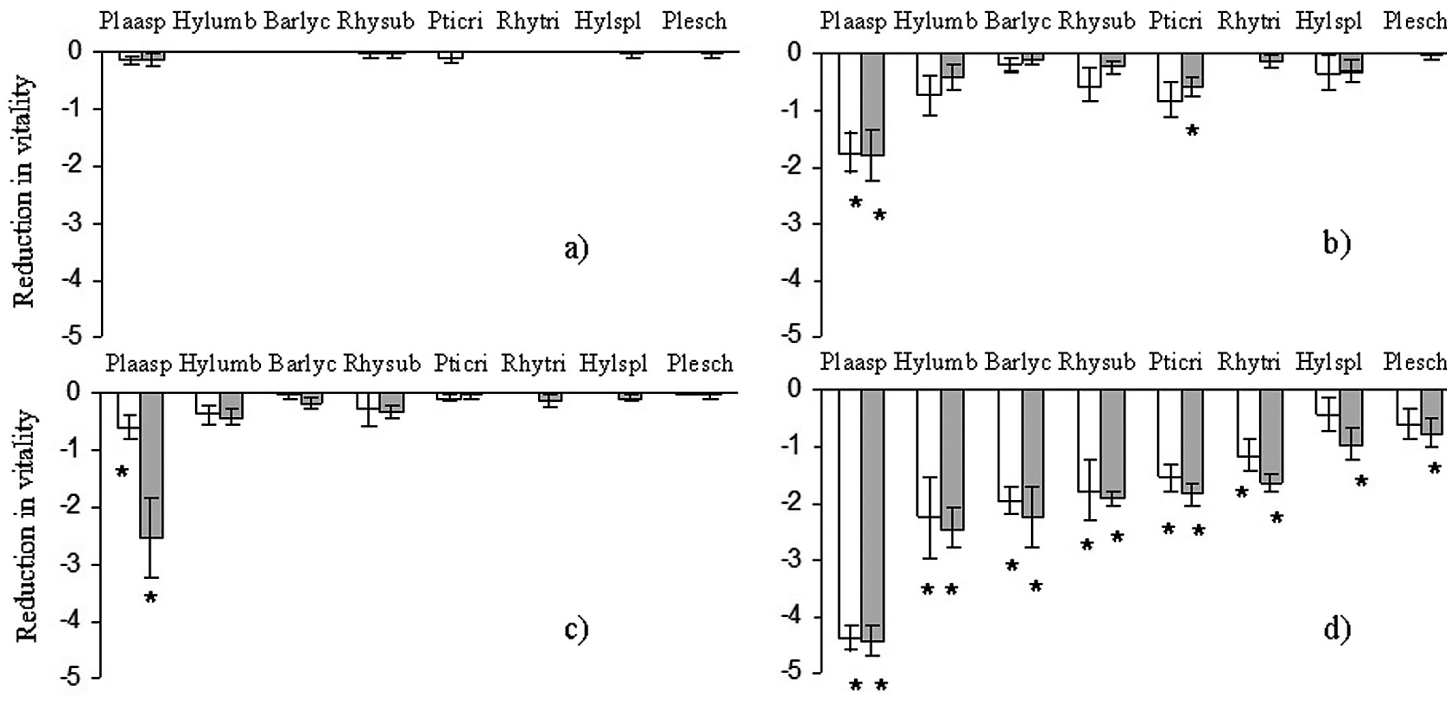

Fig. 3. Reduction in apparent vitality of transplants 4 (open bars) and 15 (shaded bars) weeks after transplantation in (a) branch-covered edge; (b) uncovered edge; (c) branch-covered centre and (d) uncovered centre. Differences in relation to initial apparent vitality (7) were tested using the Wilcoxon's signed rank test $(*$ denote significant changes, $P<0.05)$. Vitality ratings are $(1)$ entire transplant dead; (2) occasional leaves alive; (3) occasional shoots alive; (4) $<1 / 2$ transplant alive; (5) $>1 / 2$ transplant alive; (6) only occasional shoots negatively affected; and (7) the entire transplant alive and fresh. $n=7$ for all treatments. Data are means $\pm 1 \mathrm{SE}$.
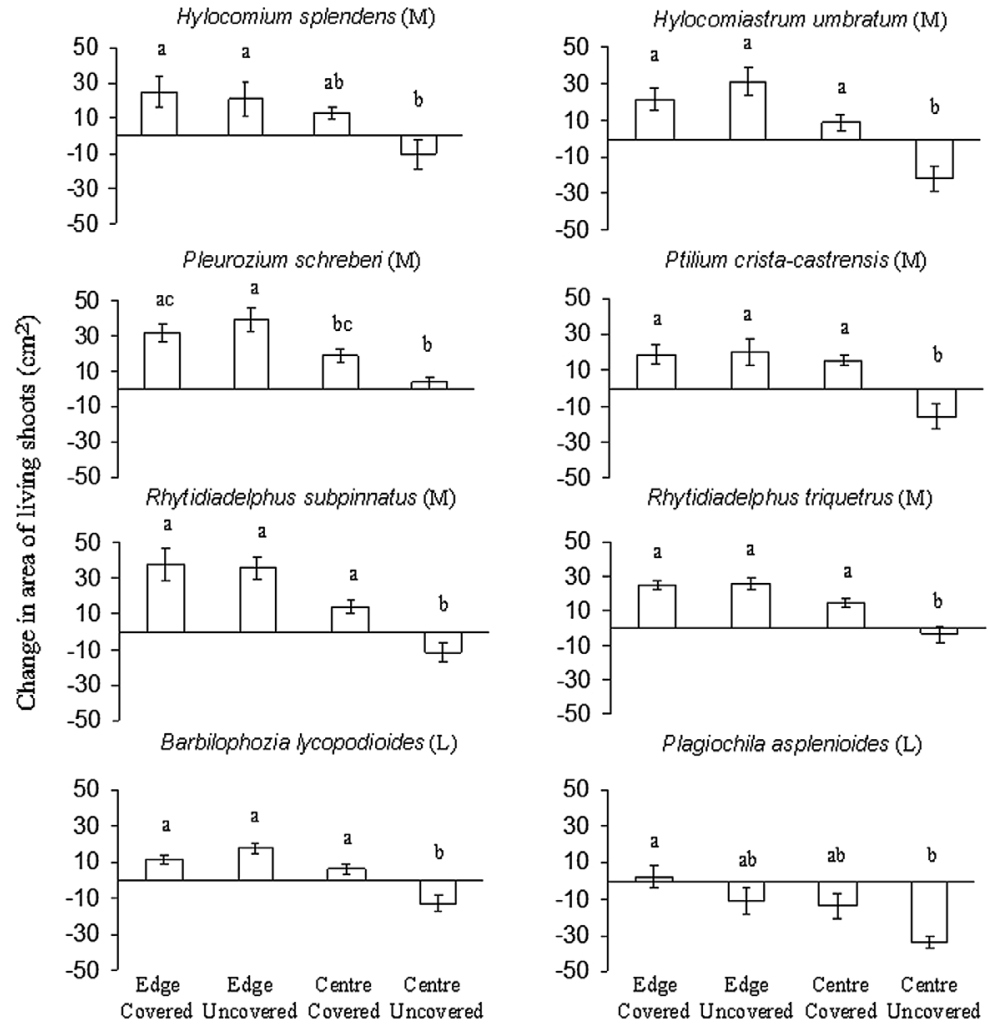

Treatment

Fig. 4. Change in area of apparently living shoots (growth minus apparent mortality) of the eight bryophyte species during the course of the experiment (15 weeks). Treatment refers to position (close to a north-facing forest edge vs in the centre of the clear-cut area) and branch cover (plots covered with Picea branches vs uncovered). (M) and (L) denote mosses and liverworts. Differences were tested with one-way ANOVA $(\mathrm{df}=3)$ and the Tukey test $(n=7$ for all treatments). All ANOVAs were significant $(P=0.00001-$ 0.018). Different letters denote significant differences between treatments according to Tukey tests. Data are means $\pm 1 \mathrm{SE}$. 
of apparently living shoots in the other three treatments was generally similar although the increase tended to be smaller in the branch-covered plots in the centres of the clear-cut areas (Fig. 4).

\section{Discussion}

Position close to a north-facing forest edge enhanced growth and apparent vitality of ground-living forest bryophytes after clear-cutting. For some species, cover by Picea branches also increased vitality (Fig. 3) and net growth (Fig. 4) in the centre of clear-cut areas whereas the effect was smaller close to forest edges. The most probable explanation for this is that position and cover modified the microclimate (Fig. 1A, B) in turn affecting bryophyte growth and shoot mortality. It is well known that there are steep microclimatic gradients through forests edges (Chen et al. 1993) and adjacent north-facing forest edges and that microstructures such as logs and stumps moderate the radiation balance in clear-cuts (Keenan \& Kimmins 1993; Burton 2002). Our results also corroborate the observation that extraction of logging residues after clear-cutting causes more extreme temperature shifts and higher daytime surface temperatures in clear-cut areas (Mahendrappa \& Kingston 1994; Proe et al. 1994, 2001). Microstructures such as stumps and branches also reduce wind velocities (Proe et al. 1994, 2001), and wind speeds were certainly lower in plots covered by Picea branches (M. Åström, pers. obs.). High wind velocities, particularly in combination with low air humidity, increase transpiration rates, the risk of water stress (Van Gardingen \& Grace 1991) and hence influence growth and vitality of bryophytes. However, as buffering effects of logging residues on wind are more important at high than at low wind velocities (Proe et al. 2001), this effect was probably more important in the centre than at the edge where wind speeds generally are lower (Chen et al. 1993).

\section{Bryophyte growth}

Wind and temperature affect ambient moisture conditions (Chen et al. 1993). Bryophytes are only metabolically active when wet and, therefore, dehydration during day-time negatively influences growth rates (Busby et al. 1978; Proctor 1990; Vitt 1990). The negative correlation between radiation and radial growth, the generally higher growth at the edges (Fig. 2) and the effect of branch cover on P. asplenioides (App. 1) show that edges and logging residues affect growth conditions. Branch cover had no significant effect on growth of other species but the tendency was always towards a negative effect at the edge but a positive effect in the centre of the clear-cut area (Fig. 2). This interaction was nearly significant for several species (App. 1) and may at least partly explain the lack of significant effect of branch cover for most species.

Although litter input may affect bryophyte growth in both directions (Busby et al. 1978; Frego \& Carleton 1995), the main effect of Picea branch cover, in our case, probably relates to light and moisture conditions. At the edge, the slightly lower growth in branch covered plots suggests that the cumulative effect of shading by adjacent trees and by Picea branches produced suboptimal growth conditions (Sveinbjörnsson \& Oechel 1992) and light saturation was probably seldom reached. At the edge, evaporative stress was also low in the uncovered plots. In central parts of clear-cut areas, however, shading by Picea branches reduced evaporative stress while radiation was still high enough to support bryophyte growth.

\section{Bryophyte vitality}

Bryophyte vitality may be rapidly affected by reduced shelter (Busby et al. 1978; Hylander et al. 2002). We also found significant reductions in apparent vitality for most species by four weeks after initial exposure (Fig. 3). Many forest bryophyte species are sensitive to high light intensities, high temperatures, extensive droughts and fluctuating microclimates (Proctor 1990; Marschall $\&$ Proctor 2004). For example, temperatures exceeding $30{ }^{\circ} \mathrm{C}$ may be lethal to bryophyte tissue (Furness \& Grime 1982) and the fact that such temperatures were frequently recorded in the uncovered plots helps explain the generally higher apparent vitality in branch covered plots (Fig. 3).

Drought sensitivity and temperature optima vary considerably among bryophyte species (Furness \& Grime 1982). In our case the two liverworts (B. lycopodioides and $P$. asplenioides) were among the three species showing lowest apparent vitality in the uncovered plots in the centre of the clear-cut areas (Fig. 3d). This is not surprising since most liverworts are more sensitive to exposure than are most mosses (Marschall \& Proctor 2004), although there is large variation in tolerance within groups. For example, the relatively closely related $H$. splendens and $H$. umbratum differ considerably in tolerance (Hylander 2005; Fig. 3d).

\section{Net change in area of apparently living shoots}

It may seem contradictory that most species had slightly higher growth in uncovered than in covered plots at the edge (Fig. 2) although their apparent vitality was generally lower (Fig. 3). However, irrespective of treatment, shoot mortality mostly occurred in the transplant centre, probably because these shoots had less 
ground contact and, thus, were more often dehydrated (M. Åström pers. obs.). Økland (2000) also found high mortality in projecting shoots of $H$. splendens. Shoots located in the periphery of the transplant were less damaged and these peripheral shoots produced the radial growth. The general increase in area of apparently living shoots of transplants sheltered by Picea branches or adjacent trees (Fig. 4) indicates that these species may survive and increase their cover in these settings, although they may be initially damaged by the abrupt change in microclimate.

\section{Soil moisture}

Bryophyte responses to clear-cutting are also influenced by environmental factors other than sheltering structures. For example, ground moisture may stimulate bryophyte growth (Hylander et al. 2002). However, mean soil moisture did not differ between treatments (Fig. 1C). In uncovered plots at the edge (where growth was highest for most species; Fig. 2) growth increased with soil water content. No such relationship was found in the other three treatments probably because lack of light (edge, branch covered) or intense light and high temperature prevented bryophytes response to variations in soil water content.

\section{Effects of transplantation}

The transplants in the forest plots from the parallel ash recycling experiment (see Methods) showed no reduction in apparent vitality. This suggests small, if any, effects of the transplantation procedure. However, there may be interactions between treatments (position and branch cover) and effects of transplantation, as suggested by the described higher shoot mortality in the centre of the transplants. Radial growth in forest transplants was similar to growth at the edge (except for $P$. asplenioides which grew 2-3 times faster in forests) but much higher than in the uncovered plot in central parts of clear-cut areas. At the uncovered edge growth ranged $31 \%-112 \%$ (among the eight species) of the growth in forests and in the uncovered centre 1 - 43\% (App. 2).

\section{Implications for harvest of logging residues}

In a previous study we found lower bryophyte cover and lower richness of liverworts, forest bryophytes, and bryophytes associated with dead wood in clear-cut areas where logging residues had been harvested ( $₫$ ström et al. 2005). Factors such as loss of woody substrate, mechanical damage during transport of slash and increased competition from vascular plants (mostly grasses) contributed to this change. Our present study suggests, however, that the microclimatic buffering by logging residue may also play a role, particularly in open settings. This capacity may also benefit other organisms intolerant to the microclimate following clear-cutting. We designed the experiment to isolate the effect on microclimate, eliminating other effects of logging residue. For example, since we removed all spontaneously establishing plants from the plots, we did not include the potentially positive influence of branch cover on bryophytes caused by reduced competition from vascular plants (Åström et al. 2005). On the other hand, a developed understorey of vascular plants also provides shelter for bryophytes intolerant to exposure (Bergamini et al. 2001). Furthermore, we included neither the function of logging residues as bryophyte substrate (Åström et al. 2005) nor the negative smothering effect of thick covers of logging residues (Jalonen \& Vanha-Majamaa 2001). The transplants were covered by a simple layer of branches on a wooden frame and no substantial negative effects of heavy shade (Fig. 2, branch-covered vs uncovered plots at the edge), smothering or litter-fall were apparent. The bryophyte shoots were able to penetrate the thin layer of litter produced by the dehiscing needles (M. Åström pers. obs.). The shading effect of cover by Picea branches diminishes successively as the needles dehisce. However, many bryophytes adapt to changing environmental conditions when these are moderate or occur slowly such as during canopy closure in spring (Kershaw \& Webber 1986). A successive increase in light when needles dehisce would at least expand their opportunity to adapt to a new environment until a new understorey develops and provides further shelter (Bergamini et al. 2001).

The buffering effects of branch cover are less pronounced in the more moderate microclimates on clear-cut areas close to north-facing edges (Figs. 1A, 2 and 4). Therefore, some of the negative effects of logging residue extraction would be mitigated by making clear-cut areas shadier and less windy. This could be obtained by smaller clear-cut areas (larger proportion of clear-cut area affected by edge-effects from surrounding forests) and some green-tree retention, practices that would also favour other organisms negatively affected by clear-cutting. This should, however, not be general practice since there are many species in the boreal region that have specialized requirements related to fire disturbance and therefore need, for example, coarse woody debris exposed to sunlight. A complementary and effective approach to secure the landscape level survival of forest species intolerant to open environments is to set aside forest patches of varying sizes such as forest reserves, key biotopes and buffer strips along small streams (e.g. 
Dynesius \& Hylander 2007), practices that are already being implemented in some boreal areas.

Acknowledgements. We are grateful to Patrik Blomberg, Sandra Karlsson, Martina Kluge, Kristin Lindström and Lotta Ström for field assistance. We also thank SCA Skog in Ångermanland for providing field data and sites, and the Swedish Meteorological and Hydrological Institute for providing climatic data. Comments by journal reviewers considerably improved the paper. This study was supported by funds from the Swedish Energy Agency (to C.N.).

\section{References}

Anon. 2004. SPSS for Windows. Version 13.0.1. SPSS, Chicago, IL, US.

Ahti, T., Hämet-Ahti, L. \& Jalas, J. 1968. Vegetation zones and their sections in northwestern Europe. Annales Botanici Fennici 5: 169-211.

Åström, M., Dynesius, M., Hylander, K. \& Nilsson, C. 2005. Effects of slash harvest on bryophytes and vascular plants in southern boreal clear-cuts. Journal of Applied Ecology 42: 1194-1202.

Åström, M., Dynesius, M., Hylander, K. \& Nilsson, C. 2007. Slope aspect modifies community responses to clear-cutting in boreal forests. Ecology 88: 749-758.

Bergamini, A., Pauli, D., Peintinger, M. \& Schmid, B. 2001. Relationships between productivity, number of shoots and number of species in bryophytes and vascular plants. Journal of Ecology 89: 920-929.

Bråkenhielm, S. \& Liu, Q. 1998. Long-term effects of clearfelling on vegetation dynamics and species diversity in a boreal pine forest. Biodiversity and Conservation 7: 207-220.

Burton, P.J. 2002. Effects of clearcut edges on trees in the sub-boreal spruce zone of north-west British Columbia. Silva Fennica 36: 329-352.

Busby, J.R., Bliss, L.C. \& Hamilton, C.D. 1978. Microclimate control of growth rates and habitats of boreal forest mosses, Tomenthypnum nitens and Hylocomium splendens. Ecological Monographs 48: 95-110.

Chen, J., Franklin, J.F. \& Spies, T.A. 1993. Contrasting microclimates among clearcut, edge, and interior of old-growth Douglas-fir forest. Agricultural and Forest Meteorology 63: 219-237.

Damsholt, K. 2002. Illustrated flora of Nordic liverworts and hornworts. Nordic Bryological Society, Lund, SE.

Doherty, S.J., Nilsson, P.O. \& Odum, H.T. 2002. Energy evaluation of forest production and industries in Sweden. Report No. 1, Department of Bioenergy, Swedish University of Agricultural Sciences, Uppsala, SE.

Dynesius, M. \& Hylander, K. 2007. Resilience of bryophyte communities to clear-cutting of boreal stream-side forests. Biological Conservation 135: 423-434.

Ellenberg, H., Weber, H.E., Düll, R., Wirth, V., Werner, W. \& Paulissen, D. 1992. Zeigerwerte von Pflanzen in Mitteleuropa. Scripta Geobotanica 18: 1-258.
Fenton, N.J. \& Frego, K.A. 2005. Bryophyte (moss and liverwort) conservation under remnant canopy in managed forests. Biological Conservation 122: 417-430.

Frego, K.A. \& Carleton, T.J. 1995. Microsite tolerance of four bryophytes in a mature Black Spruce stand, reciprocal transplants. Bryologist 98: 452-458.

Furness, S.B. \& Grime, J.P. 1982. Growth rates and temperature responses in bryophytes. II. A comparative study of species of contrasted ecology. Journal of Ecology 70: 525-536.

Gray, A.N. \& Spies, T.A. 1997. Microsite controls on tree seedling establishment in conifer forest canopy gaps. Ecology 78: 2458-2473.

Gunnarsson, B., Nittérus, K. \& Wirdenäs, P. 2004. Effects of logging residue removal on ground-active beetles in temperate forests. Forest Ecology and Management 201: 229-239.

Hägglund, B. \& Lundmark, J.-E. 1987. Handledning i bonitering med Skogshögskolans boniteringssystem. Skogsstyrelsen, Jönköping, SE.

Hallingbäck, T., Hedenäs, L. \& Weibull, H. 2006. New checklist of Swedish bryophytes. Svensk Botanisk Tidskrift 100: 96-148.

Heithecker, T.D. \& Halpern, C.B. 2006. Variations in microclimate associated with dispersed-retention harvests in coniferous forests of western Washington. Forest Ecology and Management 226: 60-71.

Hylander, K. 2005. Aspect modifies the magnitude of edge effects on bryophyte growth in boreal forests. Journal of Applied Ecology 42: 518-525.

Hylander, K., Jonsson, B.G. \& Nilsson, C. 2002. Evaluating buffer strips along boreal streams using bryophytes as indicators. Ecological Applications 12: 797-806.

Hylander, K., Dynesius, M., Jonsson, B.G. \& Nilsson, C. 2005. Substrate form determines the fate of bryophytes in riparian buffer strips. Ecological Applications 15: 674-688.

Jalonen, J. \& Vanha-Majamaa, I. 2001. Immediate effects of four different felling methods on mature boreal spruce forest understorey vegetation in southern Finland. Forest Ecology and Management 146: 25-34.

Keenan, R.J. \& Kimmins, J.P. 1993. The ecological effects of clear-cutting. Environmental Reviews 1: 121-144.

Kershaw, K.A. \& Webber, M.R. 1986. Seasonal changes in the chlorophyll content and quantum efficiency of the moss Brachythecium rutabulum. Journal of Bryology 14: 151-158.

Krok, T.O.B.N. \& Almquist, S. 1994. Svensk flora. Fanerogamer och ormbunksväxter. Liber Utbildning, Stockholm, SE.

Mahendrappa, M.K. \& Kingston, D.G.O. 1994. Intensive harvesting impacts on soil temperature and solution chemistry in the maritime region of Canada. New Zealand Journal of Forestry Science 24: 402-414.

Marschall, M. \& Proctor, M.C.F. 2004. Are bryophytes shade plants? Photosynthetic light responses and proportions of Chlorophyll $a$, Chlorophyll $b$ and total carotenoids. Annals of Botany 94: 593-603.

Minore, D. 1986. Germination, survival and early growth of conifer seedlings in two habitat types. USDAForest Service Research Paper PNW-348. Pacific Northwest Research 
Station, Portland, OR, US.

Nitare, J. (ed.) 2000. Signalarter, indikatorer på skyddsvärd skog. Flora över kryptogamer. National Board of Forestry, Jönköping, SE.

Nykvist, N. 1997. Changes in species occurrence and phytomass after clearfelling, prescribed burning and slash removal in two Swedish spruce forests. Studia Forestalia Suecica 201: 1-33.

Økland, R.H. 1995. Population biology of the clonal moss Hylocomium splendens in norwegian boreal spruce forests. 1. Demography. Journal of Ecology 83: 697-712.

Økland, R.H. 1997. Population biology of the clonal moss Hylocomium splendens in Norwegian boreal spruce forests. III. Six-year demographic variation in two areas. Lindbergia 22: 49-68.

Økland, R.H. 2000. Population biology of the clonal moss Hylocomium splendens in Norwegian boreal spruce forests. 5. Vertical dynamics of individual shoot segments. Oikos 88: 449-469.

Olsson, B.A. \& Staaf, H. 1995. Influence of harvesting intensity of logging residues on ground vegetation in coniferous forests. Journal of Applied Ecology 32: 640-654.

Proctor, M.C.F. 1990. The physiological basis of bryophyte production. Botanical Journal of the Linnean Society 104: 61-77.

Proe, M.F., Dutch, J. \& Griffiths, J. 1994. Harvest residue effect on micro-climate, nutrition, and early growth of sitka spruce (Picea sitchensis) seedlings on a restock site. New Zealand Journal of Forestry Science 24: 390-401.
Proe, M.F., Griffiths, J. \& McKay, H.M. 2001. Effect of whole-tree harvesting on microclimate during establishment of second rotation forestry. Agricultural and Forest Meteorology 110: 141-154.

Raab, B. \& Vedin, H. (eds.). 1995. National atlas of Sweden. Climate, lakes and rivers. SNA, Stockholm, SE.

Rydgren, K. \& Økland, R. 2002. Sex distribution and sporophyte frequency in a population of the clonal moss Hylocomium splendens. Journal of Bryology 24: 207-214.

Rydgren, K., de Kroon, H., Økland, R. \& van Groenendael, J. 2001. Effects of fine-scale disturbances on the demography and population dynamics of the clonal moss Hylocomium splendens. Journal of Ecology 89: 395-405.

Sveinbjörnsson, B. \& Oechel, W.C. 1992. Controls on growth and productivity of bryophytes: environmental limitations under current and anticipated conditions. In: Bates, J.W. \& Farmer, A.M. (eds.) Bryophytes and lichens in a changing environment, pp. 77-102. Oxford University Press, Oxford, UK.

Van Gardingen, P.R. \& Grace, J. 1991. Plants and wind. Advances in Botanical Research 18: 189-253.

Vitt, D.H. 1990. Patterns of growth of the drought tolerant moss, Racomitrium microcarpon, over a three year period. Lindbergia 15: 181-187.

Wastenson, L. \& Nilsson, N.-E. (eds.) 1995. National atlas of Sweden. The forests. National Board of Forestry, Jönköping, SE.

Wilcox, D., Dove, B., McDavid, D. \& Greer, D. 1995-2002. UTHSCSA Image Tool for Windows Version 3.00. University of Texas Health Science Center, San Antonio, TX, US.

Received 21 March 2007;

Accepted 9 January 2008; Co-ordinating Editor: R. Halvorsen.

For App 1 \& 2 , see below (online version) also available at JVS/AVS Electronic Archives. www.opuluspress.sel 
App. 1. Results from a two-way ANOVA for the effect of position (close to a north-facing forest edge vs in the centre of a clear-cut area) and branch cover (covered vs not covered with Picea branches) on radial growth (mm) of the eight transplanted bryophyte species. (M) and (L) represent mosses and liverworts. $n=7$ for all species and treatments. Position and branch cover are considered fixed factors.

\begin{tabular}{|c|c|c|c|c|c|}
\hline Species & $\begin{array}{l}\text { Source of } \\
\text { variation }\end{array}$ & $\mathrm{df}$ & $\begin{array}{l}\text { Mean } \\
\text { square }\end{array}$ & $F$ & $P$ \\
\hline \multirow[t]{4}{*}{ Hylocomium splendens $(\mathrm{M})$} & Position & 1 & 157.94 & 9.25 & 0.006 \\
\hline & Cover & 1 & 0.30 & 0.02 & 0.896 \\
\hline & Position $\times$ cover & 1 & 2.12 & 0.12 & 0.728 \\
\hline & Error & 24 & 17.07 & & \\
\hline \multirow[t]{4}{*}{ Hylocomiastrum umbratum $(\mathrm{M})$} & Position & 1 & 257.43 & 21.54 & 0.000 \\
\hline & Cover & 1 & 2.34 & 0.20 & 0.662 \\
\hline & Position $\times$ cover & 1 & 26.23 & 2.19 & 0.152 \\
\hline & Error & 24 & 11.95 & & \\
\hline \multirow[t]{4}{*}{ Pleurozium schreberi $(\mathrm{M})$} & Position & 1 & 281.62 & 26.75 & 0.000 \\
\hline & Cover & 1 & 0.21 & 0.02 & 0.890 \\
\hline & Position $\times$ cover & 1 & 32.57 & 3.09 & 0.091 \\
\hline & Error & 24 & 10.53 & & \\
\hline \multirow[t]{4}{*}{ Ptilium crista-castrensis (M) } & Position & 1 & 172.01 & 15.56 & 0.001 \\
\hline & Cover & 1 & 3.57 & 0.32 & 0.575 \\
\hline & Position $\times$ cover & 1 & 39.84 & 3.60 & 0.070 \\
\hline & Error & 24 & 11.06 & & \\
\hline \multirow{4}{*}{ Rhytidiadelphus subpinnatus (M) } & Position & 1 & 517.72 & 40.25 & 0.000 \\
\hline & Cover & 1 & 6.61 & 0.51 & 0.481 \\
\hline & Position $\times$ cover & 1 & 6.41 & 0.50 & 0.487 \\
\hline & Error & 24 & 12.86 & & \\
\hline \multirow[t]{4}{*}{ Rhytidiadelphus triquetrus $(\mathrm{M})$} & Position & 1 & 207.92 & 28.36 & 0.000 \\
\hline & Cover & 1 & 0.72 & 0.10 & 0.756 \\
\hline & Position $\times$ cover & 1 & 17.44 & 2.38 & 0.136 \\
\hline & Error & 24 & 7.33 & & \\
\hline \multirow[t]{4}{*}{ Barbilophozia lycopodioides (L) } & Position & 1 & 145.83 & 24.04 & 0.000 \\
\hline & Cover & 1 & 0.04 & 0.01 & 0.933 \\
\hline & Position $\times$ cover & 1 & 13.58 & 2.24 & 0.148 \\
\hline & Error & 24 & 6.07 & & \\
\hline \multirow[t]{4}{*}{ Plagiochila asplenioides (L) } & Position & 1 & 7.03 & 16.22 & 0.000 \\
\hline & Cover & 1 & 2.12 & 4.88 & 0.037 \\
\hline & Position $\times$ cover & 1 & 0.02 & 0.05 & 0.824 \\
\hline & Error & 24 & 0.43 & & \\
\hline
\end{tabular}

App. 1-2. Internet supplement to: Dynesius, M.; Åström, M. \& Nilsson, C. 2008. 
App. 2. Mean radial growth ( $\mathrm{mm}$ ) of transplants collected from forest control plots in an ash-application experiment conducted in the same area and at the same time (Mats Dynesius unpubl.). Data from the four treatments on clear-cut areas in the present study are presented for comparison. The radial growth of transplants in clear-cut areas is expressed both as mean radial growth (mm) and as proportion (\%) of the growth of transplants in forests.

\begin{tabular}{|c|c|c|c|c|c|c|c|c|c|}
\hline \multirow[t]{2}{*}{ Species } & \multirow{2}{*}{$\begin{array}{l}\text { Forest } \\
\text { Mean }\end{array}$} & \multicolumn{2}{|c|}{ Branch-covered edge } & \multicolumn{2}{|c|}{ Uncovered edge } & \multicolumn{2}{|c|}{ Branch-covered centre } & \multicolumn{2}{|c|}{ Uncovered centre } \\
\hline & & Mean & $\%$ of forest & Mean & $\%$ of forest & Mean & $\%$ of forest & Mean & $\%$ \\
\hline \multicolumn{10}{|l|}{ Mosses } \\
\hline Hylocomium splendens & 13.1 & 9.8 & 75 & 10.5 & 80 & 5.6 & 43 & 5.2 & 40 \\
\hline Hylocomiastrum umbratum & 14.2 & 8.6 & 61 & 9.9 & 70 & 4.4 & 31 & 1.9 & 13 \\
\hline Pleurozium schreberi & 12.3 & 11.4 & 93 & 13.8 & 112 & 7.2 & 59 & 5.3 & 43 \\
\hline Ptilium crista-castrensis & 12.6 & 9 & 71 & 10.7 & 85 & 6.5 & 52 & 3.4 & 27 \\
\hline Rhytidiadelphus subpinnatus & 18.1 & 13.6 & 75 & 13.6 & 75 & 6 & 33 & 4 & 22 \\
\hline Rhytidiadelphus triquetrus & 10.2 & 9.8 & 96 & 11.1 & 109 & 6 & 59 & 4.1 & 40 \\
\hline \multicolumn{10}{|l|}{ Liverworts } \\
\hline Barbilophozia lycopodioides & 9.5 & 6.1 & 64 & 7.5 & 79 & 2.9 & 31 & 1.6 & 17 \\
\hline Plagiochila asplenioides & 7.0 & 3.3 & 47 & 2.2 & 31 & 1.2 & 17 & 0.1 & 1 \\
\hline All species & 13.9 & 10.2 & 74 & 11.3 & 82 & 5.7 & 41 & 3.7 & 26 \\
\hline
\end{tabular}

App. 1-2. Internet supplement to: Dynesius, M.; Åström, M. \& Nilsson, C. 2008. 